\title{
Current Challenges in English Language Learning in Turkish EFL Context
}

\author{
Ekrem Solak \\ Department of English Language Teaching, Amasya University, Amasya, Turkey
}

\begin{tabular}{|c|c|}
\hline \multicolumn{2}{|c|}{$\begin{array}{c}\text { Adem Bayar } \\
\text { Department of Educational Sciences, Amasya University, Amasya, Turkey }\end{array}$} \\
\hline Article history & The purpose of this study was to investigate the current challenges in \\
\hline $\begin{array}{l}\text { Received: } \\
05.02 .2015\end{array}$ & $\begin{array}{l}\text { English language learning and teaching in Turkey from high and low } \\
\text { achievers' perspective. The study was qualitative in nature and the }\end{array}$ \\
\hline $\begin{array}{l}\text { Received in revised form: } \\
12.03 .2015\end{array}$ & $\begin{array}{l}\text { participants of the study were twenty-two students attending at various } \\
\text { departments of a state university in Turkey. In this study, the question } \\
\text { of "what were the challenges that you had while learning English?" }\end{array}$ \\
\hline $\begin{array}{l}\text { Accepted: } \\
\text { 134.03.2015 }\end{array}$ & $\begin{array}{l}\text { was asked to each participant and their responses were classified in } \\
\text { terms of overall ideas, language skills, method, approach, practice, }\end{array}$ \\
\hline s: & linguistic differences in two languages, personal differences, teacher, \\
\hline $\begin{array}{l}\text { foreign language education } \\
\text { in Turkey, challenges in } \\
\text { language learning, } \\
\text { language learning } \\
\text { difficulties }\end{array}$ & $\begin{array}{l}\text { material, family and environment. The results of the study suggest that } \\
\text { the objectives of English course should be realistic and be considered } \\
\text { as a whole from primary education to higher education. Teaching and } \\
\text { improving four language skills are supposed to be the focus of } \\
\text { attention rather than grammar-centred language teaching. English } \\
\text { courses should be designed as practice-based rather than theory-based. } \\
\text { In addition, foreign language teachers should take into consideration } \\
\text { the individual differences, learner characteristics and plan the } \\
\text { activities in this regard. Foreign language teachers should take in- } \\
\text { service training and update their professionalism from time to time. } \\
\text { Finally, the materials such as course books, videos, and internet web } \\
\text { sites should be chosen carefully according to the students' interest, } \\
\text { level and needs. }\end{array}$ \\
\hline
\end{tabular}

\section{Introduction}

The teaching of foreign languages has become an important part of Turkish education system since the westernization efforts of 19th century. In todays' globalized world, knowing a language is seen as an indispensable part of almost every sector in Turkey. The advances in technologies in many fields have emerged a need for a common communication tool. English is seen as a lingua franca of the world languages and this case has emphasized the importance of teaching and learning of English language both in Turkey and all over the world. So far, lots of decisions have been made, new methods and approaches have been implemented, many course books and curriculum revised through trial and error in teaching

*Correspondency: ekremsolak@gmail.com 
and learning English language in Turkey, but it has not been possible to reach the desired objectives in this field.

Therefore, the purpose of this study was to investigate the current challenges in English language learning and teaching in Turkey from high and low achievers perspective and propose some suggestions in the light of the data collected.

\section{Historical Perspective}

In Ottoman Empire, foreign language teaching was meant to teach Arabic and Persian languages due to religious purposes and the teaching of structural characteristics of those languages were the focus of attention because the purpose was to understand a written text. Within the westernization efforts, The Rescript of Gulhane contributed to the teaching of foreign languages, because this topic found its way in the new curriculum of modernized schools. In 1868, Galatasaray Sultanisi was established to teach French language at an advanced level and to meet the needs of civil servants of the Emperor (Demirel, 2003). Darussafaka Private School, which was famous for well-qualified mathematics, science and French lessons, was opened in 1873 (Demircan, 1988). Within the Proclamation of the Republic, Turkish became the primary language as the medium of instruction. The Table 1 below shows the chorological change in the priority given to foreign languages throughout recent Turkish history (Demircan, 1988).

Table 1. The chorological change of foreign languages in recent Turkish history

\begin{tabular}{llllll}
\hline Order & Pre 1773 & $1773-1923$ & $1923-1950$ & $1950-1980$ & After 1980s \\
\hline 1 & Arabic & Arabic & French & English & English \\
2 & Persian & Persian & English & French & German \\
3 & Turkish & French & German & German & French \\
4 & & English & Arabic & Arabic & Arabic \\
5 & & German & & Persian & Persian \\
\hline
\end{tabular}

In 1928, Turkish Education Foundation was established to prevent Turkish children from attending foreign schools to learn a foreign language. Between the years 1928-1934 TED College was structured and the medium of instruction at this school has been English since 1952.

Because of the advantages of knowing a foreign language in Turkey, teaching of foreign languages have been given priority by both public and private schools and Turkish education system has undergone some changes by means of trial and error through time. Anatolian high schools and super high schools have been some of the implementations on the state side. In private sector, there have been many private schools opened and the most important characteristics of these private schools have been to emphasize English language teaching. To provide the sustainability of foreign language teaching in all echelons of Turkish education system, in 1956 Middle East Technical University and in 1957 Bogazici University which was an extension of Robert College were opened and the most remarkable characteristics of these institutions was that the medium of instruction was in English. Following these universities, Bilkent University (founded in 1983), Koç University (since 1993) and Sabanc1 University (since 1997) have been some of the private universities of which the medium instruction has been in English. 


\section{Literature Review}

The current literature about the problems in language teaching and learning in Turkey found various reasons for the failure. In 2005, Gedikoğlu investigated the problems in Turkish education system in the process of entering European Union. Besides the evaluation of Turkish education system in general, problems in foreign language teaching were mentioned as well. This study revealed that the most noticeable problems in foreign language teaching were the lack of well-trained teachers and the limitation of technological utilities. In addition, this study also emphasized the role of mother tongue in learning a foreign language. Çelebi (2006) focused on foreign language education policies of Turkey and he suggested that the problems in foreign language teaching in Turkey resulted from the troubles in the teaching of the mother tongue. He also stressed that the materials and course books used in foreign language teaching did not comply with the Turkish culture, way of thought and learning styles. Altun (2006) analyzed the issue in terms of using computer technologies in Turkish education system. In this study, participants were computer coordinators, school principals, and supervisors. According to the findings of the research, the main troubles mentioned were as follows: too few computers, insufficient software, and lack of peripheral equipment at schools and insufficient number of in-service training courses for teachers. He suggested that handling with the problems in teaching English, it would be beneficial to examine the problem from the perspective of learners. Akalın and Zengin (2007) conducted a research about the perceptions of people on foreign language learning in Turkey. They revealed that there were two main problems in foreign language teaching in Turkey. The first one was the lack of realistic objectives and the second one was to spend much time on grammar teaching rather than other language skills. From the teachers' perspective, a study with regard to teaching English in multigraded classrooms was conducted by Karc1 and Vural (2011). Results of the study showed that elementary school teachers had negative views about teaching English although students' attitudes towards English were found positive. They did not consider themselves qualified enough at teaching English.

Aydin and Zengin (2008) concentrated on the role of anxiety in foreign language learning and considered the anxiety as one of the main reasons for learning a foreign language. The study found that the reasons for anxiety were the exams and negative assessment. In addition, this study also proved that other reasons for the anxiety in foreign language learning were teacher behaviors, different learning styles and cultural diversities. Büyükyavuz and İnal (2008) conducted a research on 132 in-service teachers to identify the problems in foreign language teaching and they found that there were lots of crowded classes at state schools filled with students with different language levels, learners were not guided to take responsibility of their own learning outside the classroom, language exams were typically designed either in multiple-choice format or in other traditional ways instead of projects and portfolios, for the majority of teachers professional development was nothing more than studying grammar and preparing for the Language Proficiency Examination for State Employees(KPDS) and the traditional classroom seating plan prevented effective teaching in classes.

Kızıldağ (2009) focused on the problems that primary public school teachers faced in teaching English. Semi-structured interview was implemented to 20 primary school teachers and as a result, it was stated that English language teachers experienced three main challenges while working at public primary schools in Turkey. These were ranked as (a) Institutional, (b) Instructional and (c) socio-economic. Institutional problems were due to the poor planning resulting in malfunctioning curriculum; instructional problems were the lack of 
appropriate materials and infrastructure. Next, socio-economic levels of the parents affected the awareness of the importance of learning a foreign language. Moreover, she maintained that ELT teachers were negatively affected by crowded classrooms and the heavy workload and the schools lacked supporting materials such as videos/CDs, projectors and computers. Gökdemir (2010) conducted a research analyzing the problems in foreign language teaching at the university level. Participants of the study were 460 English preparatory class students from various universities in Turkey. He found that the main challenges were: English lessons were mostly theory-based rather than practice-based, English lessons were generally teachercentered rather than learner-centered, there was no convenient environment for learning a foreign language, the students attending preparatory classrooms and schools at the universities did not have enough supplementary materials in English.

According to Çetintaş (2010), the most important problem in foreign language teaching in Turkey was the lack of sustainability from the primary school to secondary education. She revealed that there was no sustainability in terms of course books and curriculum throughout the education. Furthermore, insufficient number of teachers who graduated from English language teaching departments and their lack of in-service training were the other reasons for the failure. Aydin (2013) analyzed teachers' perception about the use of computers in teaching English and participants of the study were 157 Turkish EFL teachers working at the elementary and secondary schools. The results of the study showed that participants had problems concerning with the integration of technology into the curriculum. He also stressed that teacher training programs did not give enough education about the computer software programs and there were deficiencies in the technical equipment of schools to integrate computers into the teaching curriculum of English lessons. Finally, Öz, Demirezen and Pourfeiz (2015) investigated the willingness to communicate of English as a foreign language (EFL) learners. They found that more opportunities should be given to EFL learners to communicate in a stress free classroom environments.

\section{Method}

This study was qualitative in nature, because it was designed to investigate the language learners' perceptions towards the current challenges that they faced in learning English from the high achievers and low achievers' perspective. The participants of the study were twenty-two students attending at various departments of a state university in Turkey. There were two groups of participants. Twelve of them attended English Language Teaching department as junior students and they studied English at secondary and high schools, too. They also passed language proficiency exam and achieved a high level in English proficiency. Other twelve participants were from the departments such as nursery, psychological counseling, math, science education and they had a low proficiency in English Language. They studied English language throughout their academic life, but they couldn't reach the desired proficiency in comparison with the first group. In this study, the question of "what were the challenges that they had while learning English?" was asked to each participant and their responses were classified in terms of language skills, method, approach, practicality, linguistic differences in two languages, individual differences, curriculum, teacher, materials, family and entourage. 


\section{Findings and Discussion}

The data collected was presented under the following themes and remarkable responses of the participants were given in text-format below.

1. Overall idea: Some participant students talked about their overall idea on English learning. For instance, one of the participants stated:

It is very upset to admit that when I came to the university, I recognized that I did not know how to speak English. This clearly shows that we do not reach the aim of language education. It is unfortunate for me and my future career (Participant 3, personal communication).

The perspective of another participant student was very similar to that of the above student. She said that:

As you know, we are in the journey of language acquisition from $4^{\text {th }}$ grade till now, in other words, for 15 years. However, when I examine myself, my English level is very low like $3^{\text {rd }}$. grade student. I am very upset to say that I just know whatever I have learned during my personal experience (Participant 11, personal communication).

This result was consistent with the findings of Akalin and Zengin (2007) who found that foreign language teaching in Turkey had lack of realistic objectives.

2. Four skills: Some participant students reported that even though English education should be based on four skills at the same time, teaching grammar has been mostly focused in their English education classes. For example, one of the participant students stated:

To tell the truth, we did not get any learning activities about speaking, listening, and writing with the exception of grammar. Yes, we know English at some level in terms of grammar; but, unfortunately, we do not know how to live in English" (Participant 3, personal communication).

The perspective of another participant student was very similar to that of the above student. He said that:

While learning English, we just care about how much we know grammar. On the other hand, it is not important how much we can speak in English in real life situations (Participant 10, personal communication).

This result was coherent with the findings of Akalin and Zengin (2007) and Büyükyavuz and İnal (2008) who stated that grammar teaching was the focus of attention rather than other language skills.

3. Method: The researchers came to know that some participant students criticized the method of English teaching. For instance, one of the participant students stated:

Even though all countries around the world have focused on communication skills and student centered education in English, we are still trying to teach and learn through 
traditional method. In this context, we are mostly focusing on just grammar but ignoring speaking and writing skills (Participant 4, personal communication).

In a similar vein, another participant student said that:

Our homework was just learning new vocabularies by writing 5 times. That was it. Otherwise, I did not remember that our English teachers did speak English in the classroom when I was a student at elementary and secondary school. Grammar translation method was the only one used at that time (Participant 7, personal communication).

This result was consistent with the findings of Kizıldağ (2009) who found that instructional issue in English teaching was very important in order to reach the aim of English teaching in Turkey. Similarly, the result was coherent with the findings of Gökdemir (2010) who reached the conclusion that the main challenges in English teaching was focusing on mostly theory-based rather than practice-based and generally teacher-centered rather than learner-centered.

4. Approach: Some participant students mentioned that there were negative attitudes towards English learning when they were students at secondary school and high school. For example, one of the participant students affirmed that:

As you know, we have to take University Entrance Examination for Higher Education by the final year of high school. That is why; English lesson, unfortunately, was considered trivial lesson such as music, art, and so on when we were students at high school (Participant 3, personal communication).

The perspective of another participant student was very similar to that of the above student. He uttered that:

When I was a student at elementary school or middle school, English lesson was not as important as other lessons like Mathematics, Geometry and etc. Therefore, school administration and our teachers did not care about what we learned in English lessons (Participant 7, personal communication).

This result was coherent with the idea of Aydın and Zengin (2008) who stated approach, in other words, attitudes towards English lesson was important for English teaching and learning.

5. Practice: Besides, some participant student uttered that they did not get the chance of practice while learning English. For example, one of the participant students stated that:

In point of fact, one of the difficulties of learning a language was the lack of exposure and input. I had less opportunity to read and to speak to a native speaker to improve my English and speak fluently (Participant 15, personal communication).

The perspective of another participant student was very similar to that of the above student. She said that: 
I have never been to the United Kingdom and/or the United States of America. Therefore, I could not find any chance to practice my speaking skills in English in real life situations. We just learned in English lessons. Even worse, we did not read any journal or newspaper in English for a long time when we were learning English (Participant 6, personal communication).

This result was consistent with the findings of Akalın and Zengin (2007) and Büyükyavuz and İnal (2008) who found that lack of practice was one of the most important aspects in English teaching.

6. Structure of languages: The researchers also recognized the importance of structure of language in English teaching and learning process. For example, one of the participant students avowed:

Actually, one of the biggest problems in English learning is the differences between writing and pronunciation of most vocabulary items in English. In addition to that, even though we do not have some tenses in Turkish, there exist some unusual tenses in English. This was another handicap for me when I was learning English (Participant 9, personal communication).

In a similar vein, another participant student expressed that:

When I was learning English, I had difficulties on learning of phrasal verbs. Actually, I still do not know what the meaning of many phrasal verbs is and am not sure which phrasal verb is the best to explain my idea when I am writing (Participant 11, personal communication).

This result was coherent with the idea of Gedikoğlu (2005) and Çelebi (2006) who emphasized the importance of the role of mother tongue in learning a foreign language.

7. Personal differences: Some participant students talked about the reality and effects of personal differences in English teaching and learning. For example, one of the participant students confirmed that:

Students are so much afraid of failure and being insulted or made fun of, therefore they are unwilling to participate in the lesson. When it comes to motivation, in my opinion it plays the most important role in the learning process. Even if you have all the other features you cannot learn a language unless you don't have enough motivation, self confidence etc. Your learning process will definitely result in failure if you don't trust yourself and a forcing effect no matter how hard you try (Participant 15, personal communication).

The perspective of another participant student was very similar to that of the above student. She said that:

Lack of motivation is one of the most important problems in English learning. If a person has less self-confidence to try talking English in front of people, he or she never begins speaking or improves his or her speaking skills (Participant 4, personal communication). 
This result was consistent with the findings of Aydin and Zengin (2008) who found the importance of different learning styles in English teaching and learning.

8. Teacher: The need of highly qualified teachers in any education system has been accepted by many researchers in the world. In this regards, some participant students stressed the importance of teacher in English education. For example, one of the participant students uttered that:

It is very hard to accept that our English teacher was so weak on educational science and classroom management. He did not use different methods when we were taking English lesson. We were mostly passive and just sit and listened although our English teacher was active. (Participant 4, personal communication).

The perspective of another participant student was very similar to that of the above student. He said that:

Unfortunately, I could not meet any highly qualified English teacher when I was a student in middle school and high school. Especially, some of them tried to teach us English by Turkish. It means that they are not well prepared in English teaching (Participant 2, personal communication).

This result was coherent with the findings of Aydın (2013), Çetintaş (2010), Gedikoğlu (2005) and Karcı and Vural (2011) who found that one of the most significant problems in foreign language teaching was the lack of well-trained teachers.

9. Material: The researchers have also come to know that some participant students have faced difficulties because of lack of material on English lessons. For instance, one of the participant students avowed:

Unfortunately, we could not use teaching materials effectively. In addition to that, materials are not appropriate for English education. For example, our English books have been written by Turkish authors who do not know exactly the culture of English (Participant 4, personal communication).

This result was consistent with the findings of Çelebi (2006), Çetintaş (2010), Gedikoğlu (2005), Gökdemir (2010), and Kızıldağ (2009) who found that one of the most significant problems in foreign language teaching was the lack and/or limitation of materials and technological utilities.

10. Family, friends and social environment: Some participant students declared that their family, friends, and social environment either negatively or positively affected their English learning. For example, one of the participant students stated that:

I had less motivation for English lesson, because, my family had negative attitudes towards English learning. According to them, English was not necessary for University Entrance Examination; therefore, studying English was just waste of time (Participant 4, personal communication). 
The perspective of another participant student was very similar to that of the above student. She said that:

Unfortunately, most of my friends did not care about what's going on in English lessons when I was a student at high school. This social environment affected my desire to learn English. Over time, I had lost my motivation on learning English and finally I became like my classmates (Participant 1, personal communication).

This result was coherent with the findings of Büyükyavuz and İnal (2008), Kızıldağ (2009), and Öz, Demirezen and Pourfeiz (2015) who emphasized the importance of family, friends, and social environment on English education.

\section{Conclusion}

In conclusion, Although Turkish education system has undergone some renewal activities including foreign language education from time to time; this study shows that there are still recurring challenges for language learners in Turkish context. This study suggests that the objectives of English course should be realistic and be considered as a whole from primary education to higher education. In other words, new topics should be introduced at each level and language level should be upgraded at each level instead of repeating the same topics again and again. Next, teaching and improving four language skills are supposed to be the focus of attention rather than grammar-centered language teaching. Because foreign language learners mostly complain that they are unable to express their ideas in English language though they have taken many English courses throughout their academic background. In addition, English courses should be designed as practice-based rather than theory-based and this learning environment can be created in a learner-centered atmosphere.

As in many other educational fields, the role of the language teacher is primarily important in motivating the learners to reach the objectives. Therefore, the methods, approaches and techniques used by the teacher affect learners' attitude towards English course positively or negatively. Foreign language teachers should take into consideration the individual differences, learner characteristics and plan the activities in this regard. Foreign language teachers should take in-service training and update their professionalism from time to time.

Finally, the materials such as course books, videos, internet web sites should be chosen carefully according to the students' interest and level. The course books which are prepared in this direction can be an effective tool in reaching educational objectives. Especially the course books designed according to the learners' needs can motivate learners in a large extent.

\section{References}

Akalın, S. \& Zengin, B. (2007). Türkiye'de halkın yabancı dil ile ilgili algıları. [The Attitude of People towards Foreign Language in Turkey]. Journal of Language and Linguistics Studies, 3(1), 181-200.

Akbaba-Altun, S. (2006). Complexity of integrating computer technologies into education in Turkey. Educational Technology \& Society, 9 (1), 176-187.

Aydin, S. (2013) Teachers' perceptions about the use of computers in EFL teaching and learning: the case of Turkey, Computer Assisted Language Learning, 26:3, 214-233. 
Aydın, S. \& Zengin, B. (2008). Yabancı dil eğitiminde kaygı: bir literatür özeti. [The Anxiety in Foreign Language Education: A literature review]. The Journal of Language and Linguistic Studies, 4 (1), 81 - 94.

Buyukyavuz O. \& Inal S (2008). A descriptive study on Turkish teachers of English regarding their professional needs, efforts for development and avail-able resources. The Asian EFL Journal, 10: 215-234.

Çelebi, D. (2006). Turkıye'de anadili egitimi ve yabancı dil ogretimi. [The Mother Tongue and Foreign Language Education in Turkey]. Erciyes Üniversitesi Sosyal Bilimler Enstitüsü Dergisi, 21 (2), 285-307.

Çetintaş, B. (2010). Türkiye'de yabancı dil Eğitim ve öğretiminin sürekliliği. [The Sustainability of Foreign Language Education in Turkey]. Journal of Language and Linguistic Studies, 6, (1), 65-74.

Demircan, O. (1988). Dünden bugüne Turklye'de yabancı dil. [Foreign Language Education in Turkey from past to present]. İstanbul: Remzi Kitabevi.

Demirel, O. (2003). Yabaci dil ögretimi.[ Foreign Language Education]. İstanbul: Pegem Yayıncilik.

Gedikoğlu, T. (2005). Avrupa Birliği sürecinde Türk eğitim sistemi: sorunlar ve çözüm önerileri. [Turkish Education System during the process of accession to European Union: problems and suggestions]. Mersin Üniversitesi Ĕ̈itim Fakültesi Dergisi, $1(1), 66-80$.

Gökdemir, C. V. (2010). Üniversitelerimizde verilen yabancı dil öğretimindeki başarı durumumuz. [The state of success in Foreign Language Education at our universities]. Erzurum Üniversitesi, Sosyal Bilimler Enstitüsü Dergisi, 6 (2), 251-264.

Karci, C., \& Akar-Vural, R. (2011). Teachers'’ views with regard to teaching English in multigraded classrooms. Ankara: TED Üniversitesi.

Kizıldag, A. (2009). Teaching English in Turkey: Dialogues with teachers about the challenges in public primary schools. International Electronic Journal of Elementary Education, Vol.1, Issue 3, June, 2009.

Mirici, İ.Hakk1. (2003). Ülkemizde neden İngilizce öğretemiyoruz? [Why can’t we teach English in our country]. Bilim Yolu. Say1 3 ss.377-386.

Öz, H., Demirezen, M., \& Pourfeiz, J. (n.d.). Willingness to communicate of EFL learners in Turkish context. Learning and Individual Differences, 37, 269-275. Retrieved January 11, 2015, from doi:10.1016/j.lindif.2014.12.009. 